\title{
Stepping Westward
}

\author{
I. MCKeith, Lecturer in Psychiatry, The Royal Victoria Infirmary, Newcastle upon Tyne
}

"When early summer with its bright clear days has brought the academic year to a close, emptying chalky classrooms and leaving books at rest on library shelves, then academic folk long to go on pilgrimages."

(Malcolm Bradbury)

In 1985 the Education Committee of the College offered for the first time a Travelling Fellowship, enabling a senior registrar or newly appointed consultant to "travel abroad, to one or two centres, for a period of not less than three months, in pursuit of further study, research or clinical training." Having convinced myself that true scientific knowledge must surely be isolated on the other side of the Atlantic, I compiled my application (three copies) and fingers crossed, sent it in. As a result I found myself in January 1986 at Dulles International Airport, Va., having arranged to spend four months at the Clinical Neurosciences Branch of the National Institute of Mental Health in Washington DC. Being a clinician with a particular interest in brain neurochemistry, the primary purpose of my mission was to see a large multidisciplinary neuroscience research team at first hand. In addition I hoped to learn of new techniques of investigation and to observe one form of American psychiatric practice. To condense these experiences into a few succinct paragraphs is a far more difficult task than preparing the original submission-but I have tried.

My first study period was based at the imposing glassfronted multistorey Clinical Center at the hub of the NIH campus, standing in the fasionable and expensive suburb of Bethesda, ten miles north-west of the centre of Washington. My host, Dr David Pickar, Chief-Section on Clinical Studies, had suggested (partially to help with the application process) that I start by learning a simple receptor binding assay labelling neuronal $\mathrm{NaK}$ ATPase sites in brain homogenates. This I did in their well equipped but densely populated laboratories which I found reassuringly similar to those I was used to at home. (No need for those sleepless nights!) Between bench sessions I was encouraged to join numerous clinical rounds, the emphasis of which was to monitor the progress of and adherence to the exhaustive research protocols. Since patients were clearly aware that this was the primary reason for their stay at NIH their degree of participation was usually high and they clearly derived satisfaction from being a part of the 'team'. I was reassured to see that the clinical commitment of the researchers ensured that their patients' welfare came first and clinical management considerations would often take precedence to the requirements of the protocol. For the remainder of my time in the Clinical Center I was able to attend my selection from the large daily programme of lectures and seminars.
Built after the Civil War on a chosen site to represent the centre of Federal Government, Washington DC and its surroundings offered numerous distractions outside working hours. The design of the city itself is reminiscent of Versailles, having been laid out by a French military engineer Pierre Charles L'Enfant, and has a gridiron of vertical and horizontal streets crossed by grand diagonal avenues. The most famous of these, Pennsylvania Avenue contains the White House. From the top of the needle-like Washington Monument, 'tidemarked' one third of the way up where building work was delayed in 1855 because of lack of funds, one could survey the Capitol, the picturesque Jefferson Memorial in its cherry tree lined Tidal Basin (the cherry trees, a gift from the Japanese were almost removed after World War 2), the macabre Pentagon building with its 17 miles of reinforced corridors, one could continue almost indefinitely. If all else fails I shall return to Washington as a city guide!

In total contrast to this central showpiece composed of finest white marble was the site of my second workplace, St Elizabeth's Hospital, founded in $\mathbf{1 8 5 2}$ as the Government Hospital for the Insane and placed in the centre of impoverished, black Anacostia. One prayed for the car not to break down on the trips in and out of the hospital grounds. (It did of course!) This was the anonymous 'Central Hospital' of Irving Goffman's book Asylums and some of his remarks of 30 years ago still appeared pertinent. Based within St Elizabeth's was the Biological Psychiatry Branch of NIMH, the post mortem brain research programme which I joined under the supervision of Dr Joel Kleinman. Here I learned about the functional neuroanatomy of the limbic system and undertook a series of multiple dissections from schizophrenic, suicide and control brains, the tissue to be used for a range of neurochemical investigations including my own Na K ATPase assay. This research group, which included Dr Dan Weinburger and Dr Janice Stevens, was involved in a range of neuropathological, neurophysiological, neurochemical, neuropsychological and image analysis studies, predominantly into schizophrenia. I was able to view all of this on one site and felt at St Elizabeths to be part of a coordinated multidisciplinary research team in which the atmosphere was conducive to working and learning. I left it reluctantly.

Four months is clearly an insufficient period in which to tap even a small part of the resources of a centre such as the NIMH. Being there only a short time may, however, have increased the intensity of my experiences and helped me to achieve the broader view without becoming excessively involved in the minutiae of detail. My next aim may be to return to do the latter. If asked to summarise the benefits accrued I think that the visit has both encouraged my own research efforts and initiatives and alerted me to looking 
beyond my own immediate horizons for further stimulation. During my stay I was offered tremendous personal hospitality and learned advice and guidance at work; I would particularly like to thank my friends David Pickar and Joel Kleinman. The generosity of the US Public Health Service for allowing me full and free use of their facilities must also be acknowledged.
In these days of cutbacks and reduced spending on academic medicine the Squibb Fellowship has offered me an opportunity to obtain additional experience of my own choosing. The effort expended in preparing an application is far outweighed by the probable rewards. If you are eligible and have some idea of what you would like to do, my advice is "go for it".

\section{Letters to the President}

\section{HIV Infection and AIDS}

\section{Dear Dr Bewley}

I am writing to seek your support and that of your colleagues in the surveillance of the acquired deficiency syndrome and in the detection of other diseases related to HIV infection.

The national surveillance scheme for AIDS is based mainly on voluntary confidential reports by clinicians to this Communicable Disease Surveillance Centre. As you will appreciate most of these reports have come from genitourinary physicians but as cases have occurred outside the risk group of homosexuals, other clinicians have contributed to this national surveillance scheme.

It occurs to me that cases may present to psychiatrists, not all of whom may be aware of the reporting scheme and I wondered if you could help us by bringing it to their attention. If you thought it was useful, I would be happy to give you a note describing the scheme and let you have a copy of the report form.

The second point I wanted to raise was whether you and your colleagues are aware of psychiatric conditions associated with HIV infection in patients who do not have AIDS? I ask this because I do not know if there is indeed a problem and if so whether we should not be considering a special means of surveillance.

\section{N. S. Galbraith}

Director

Public Health Laboratory Service

PHLS Communicable Disease Surveillance Centre

61 Colindale Avenue

London NW9 SEQ

\section{Mental Health Act 1983}

\section{Dear Dr Bewley}

At a recent public meeting, organised by one of our local Groups, a consultant psychiatrist stated that the only grounds for compulsory admission to hospital were danger to self or others. This is only the latest of a number of such instances coming to our notice, of seeming ignorance of the law on the part of consultant psychiatrists.

We realise that statements like this arise from exasperation with the excessive emphasis given to personal liberty by review tribunals and the draft Code of Practice; but we feel that this prevalent imbalance makes it particularly important to take every opportunity for making clear what the law actually says.

Less surprisingly perhaps, there is similar ignorance elsewhere.

A particularly unfortunate example of this omission of the alternative ground for 'sectioning'-in the interest of the health of the patient-occurred in the address given by the 'guest speaker' on mental health (a social worker) to the DHSS training course for Special Case Officers in local DHSS offices. We called the attention of the DHSS to this-with what results we do not know.

We would like to suggest that this misunderstanding is serious enough to warrant a reminder by the Royal College, to its members in this country, of the wording of the Act; coupled perhaps with-or disguised as-encouragement to do what is possible to correct such misapprehensions in other quarters.

I would be very grateful for your views on this issue which is of critical concern to a number of our members. JUDY WELEMINSKY Director

National Schizophrenia Fellowship

78 Victoria Road

Surbiton, Surrey 